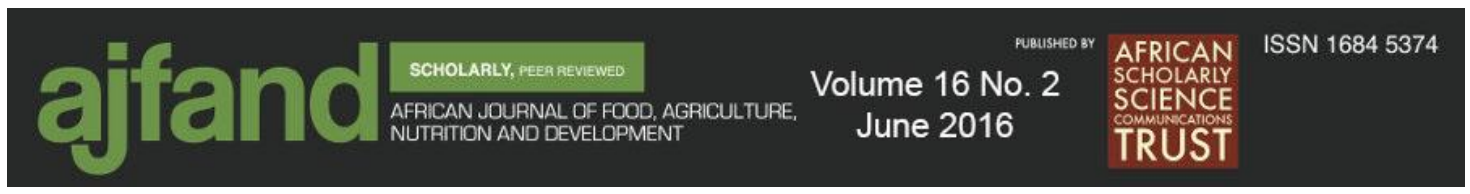

DOI: 10.18697/ajfand.74.15305

\title{
STANDARDIZATION OF CASSAVA MAHEWU FERMENTATION AND ASSESSMENT OF THE EFFECTS OF IRON SOURCES USED FOR FORTIFICATION
}

\author{
Salvador EM${ }^{1,2}$, McCrindle $\mathrm{CME}^{1 *}$, Buys $\mathrm{EM}^{3}$ and V Steenkamp ${ }^{4}$
}

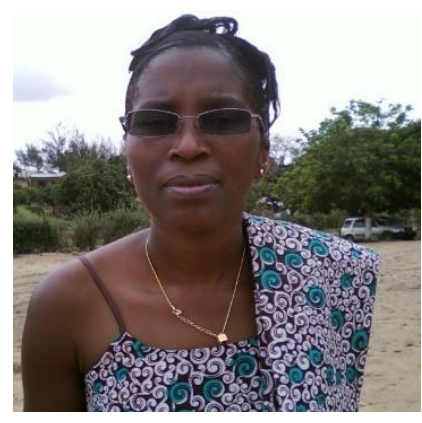

Elsa Maria Salvador

*Corresponding author email: cheryl.mccrindle@ gmail.com

${ }^{1}$ School of Health Systems and Public Health, Faculty of Health Sciences, University of Pretoria, Private Bag X323, Pretoria 0001, South Africa

${ }^{2}$ Department of Biological Sciences, Faculty of Sciences, Eduardo Mondlane University, Av. Julius Nyerere, P.O. Box 257, Maputo, Mozambique

${ }^{3}$ Department of Food Science, Faculty of Natural and Agricultural Science, University of Pretoria, Private bag X20, Hatfield, Pretoria 0028, South Africa

${ }^{4}$ Department of Pharmacology, Faculty of Health Sciences, University of Pretoria, Private Bag X323, Arcadia, Pretoria 0007, South Africa 


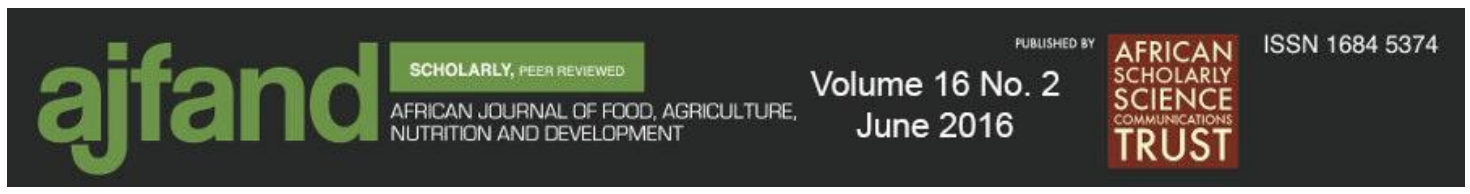

\begin{abstract}
Cassava root is the main staple for $70 \%$ of the population in Mozambique, particularly in inaccessible rural areas, but is known to be low in iron. Anaemia is a public health problem in mothers and preschool children in Mozambique and up to $40 \%$ of these cases are probably due to dietary iron deficiency. The World Health Organization (WHO) and Food and Agriculture Organization of the United Nations (FAO) recognize the fortification of foodstuff as an effective method to remedy dietary deficiencies of micronutrients, including iron. Cassava mahewu, a non-alcoholic fermented beverage is prepared at subsistence level from cassava roots using indigenous procedures. The aim of the study was to standardize mahewu fermentation and investigate if the type of cassava fermented, or the iron compound used for fortification affected the final product. Roots of sweet and bitter varieties of cassava from four districts (Rapale, Meconta, Alto Molocue and Zavala) in Mozambique, were peeled, dried and pounded to prepare flour. Cassava flour was cooked and fermented under controlled conditions $\left(45^{\circ} \mathrm{C}\right.$ for $24 \mathrm{~h}$ ). The fermentation period and temperature were set, based on the findings of a pilot study which showed that an end-point $\mathrm{pH}$ of about 4.5 was regularly reached after $24 \mathrm{~h}$ at $45^{\circ} \mathrm{C}$. Cassava mahewu was fortified with ferrous sulfate $\left(\mathrm{FeSO}_{4} .7 \mathrm{H}_{2} \mathrm{O}\right)$ or ferrous fumarate $\left(\mathrm{C}_{4} \mathrm{H}_{2} \mathrm{FeO}_{4}\right)$ at the beginning (time zero) and at the end of fermentation $(24 \mathrm{~h})$. The amount of iron added to the mahewu was based on the average of the approved range of iron used for the fortification of maize meal. The mean $\mathrm{pH}$ at the endpoint was 4.5, with $0.29 \%$ titratable acidity. The $\mathrm{pH}$ and acidity were different to those reported in previous studies on maize mahewu, whereas the solid extract of $9.65 \%$ was found to be similar. Lactic acid bacteria (LAB) and yeast growth were not significantly different in mahewu fortified with either of the iron compounds. There was no significant difference between cassava mahewu made from bitter or sweet varieties. A standard method for preparation and iron fortification of cassava mahewu was developed. It is recommended that fortification occurs at the end of fermentation when done at household level.
\end{abstract}

Key words: Cassava mahewu, fermentation, ferrous fumarate, ferrous sulfate, iron fortification, Mozambique 


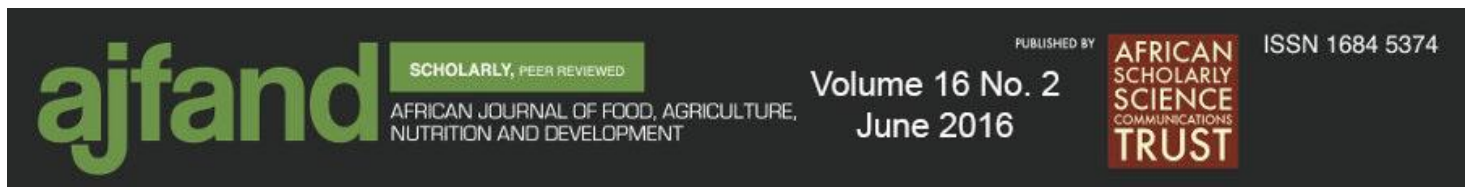

\section{INTRODUCTION}

Cassava is consumed by more than $70 \%$ of the population in Mozambique and is considered the staple food [1]. A popular form in which cassava is consumed is as mahewu. Mahewu is a non-alcoholic fermented beverage consumed traditionally in African nations and Arabian Gulf countries [2]. In Africa, it is estimated that an adult black person consumes between 12 and $14 \mathrm{~L}$ of commercial mahewu. However, people across the continent provide for their needs by making home-made mahewu [2]. It is made by fermenting maize, sorghum and millet malt or wheat flour [2]. Spontaneous fermentation is frequently due to lactic acid bacteria (LAB) and yeast, with the former being the predominant fermentation agent [2]. Maize mahewu has been produced at commercial levels in African countries such as Botswana, South Africa and Zimbabwe [3-5]. At commercial level, maize mahewu has been enriched with minerals and vitamins to improve the nutritional value [6]. Fermentation promotes the bioavailability of minerals such as calcium, iron and zinc [2]. No published information on cassava mahewu fermentation could be found at the time of this study, but it is likely that, as for maize, fermentation would increase the protein concentration and the bioavailability of amino acids and minerals [7].

Anaemia is considered to be a serious public health problem in Mozambique and it is estimated that about $40 \%$ of cases are due to dietary iron deficiency [8]. Fortification of maize mahewu has proved effective in providing dietary iron. Ferrous sulfate $\left(\mathrm{FeSO}_{4} .7 \mathrm{H}_{2} \mathrm{O}\right)$ and ferrous fumarate $\left(\mathrm{C}_{4} \mathrm{H}_{2} \mathrm{FeO}_{4}\right)$ have been used for iron fortification of several food staples including maize flour in countries such as Brazil, Mexico and Venezuela [9]. Ferrous sulfate is a water soluble iron source, recommended for the fortification of de-germed maize flour and flours with a short shelf life [10]. Ferrous fumarate is poorly soluble in water and is also used for maize flour fortification [11]. The absorption of iron from fortified food depends on the chemical composition of the iron compounds used and the presence of enhancers [11]. Iron fortification of food with ferrous sulfate has been shown to significantly increase serum ferritin and hemoglobin levels and decrease dietary anaemia in women of reproductive age [12]. According to the WHO, iron compounds recommended for fortification of wheat and maize include ferrous sulfate, ferrous fumarate, and sodium iron EDTA (NaFeEDTA) [13]. Only ferrous fumarate and ferrous sulfate were commercially obtainable and were, therefore, used in this study.

The aim of the study was, therefore, to standardize mahewu fermentation and compare whether fermenting sweet or bitter cassava, the variety of cassava fermented, or the iron compound used for fortification affected the final product.

\section{MATERIALS AND METHODS}

\section{Cassava}

Cassava roots were collected from four different geographical regions in Mozambique where sweet or/and bitter types were predominant. Sweet cassava roots (two different varieties Calamidade and Munhaça) were collected from Meconta District in Nampula Province and Zavala District in Inhambane Province, respectively. Bitter cassava roots 


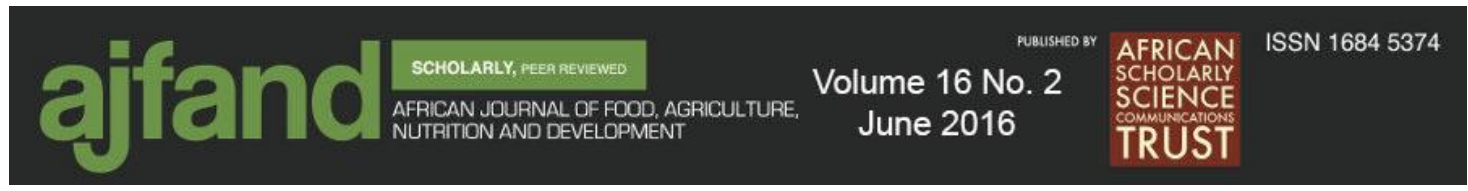

(Tomo and Incirricano varieties) were collected from Rapale District in Nampula Province and Alto Molocue District in Zambézia Province, respectively.

\section{Cassava flour preparation}

Indigenous methods and implements were used to make cassava flour. Roots were peeled, washed with tap water, grated with a plastic grater and sun-dried for two to three days. The dried roots were manually pounded with a traditional wooden pestle and mortar and then sieved into flour, which was boiled with water to make porridge prior to fermenting. The proportions are elaborated on below.

\section{Mahewu preparation}

Cassava flour was fermented using the method described by Mutasa and Ayebo [3] and Bvochora et al. [4] for maize mahewu, with minor changes. Initially $20 \mathrm{~g}$ cassava flour was mixed with $49 \mathrm{~mL}$ of distilled water and added to $150 \mathrm{~mL}$ of boiling water. The mixture was boiled for 10 min to gelatinize the starch then cooled to a temperature of $25^{\circ} \mathrm{C}$. The porridge was transferred to a $250 \mathrm{~mL}$ Erlenmeyer flask and $1.25 \mathrm{~g}$ of starter culture (freeze-dried cassava mahewu previously prepared traditionally), was added and mixed thoroughly.

Modifications of the methodology suggested by Mutasa and Ayebo [3] and Bvochora et $a l$. [4] included the type of substrate used ( $20 \mathrm{~g}$ cassava flour instead of $15 \mathrm{~g}$ of maize or sorghum meal); starter culture (1.25 g of freeze dried cassava mahewu instead of $7.5 \mathrm{~g}$ of sorghum malt); temperature and fermentation period $\left(24 \mathrm{~h}\right.$ at $45^{\circ} \mathrm{C}$ and not $36 \mathrm{~h}$ at $30^{\circ} \mathrm{C}$ ); and, iron fortification (no fortification was done with the maize mahewu).

A pilot study had determined that an end-point of approximately $\mathrm{pH} 4.5$ was consistently reached after $24 \mathrm{~h}$ at $45^{\circ} \mathrm{C}$, after which the $\mathrm{pH}$ stabilized [14]. Thus, the broth was fermented at $45^{\circ} \mathrm{C}$ for $24 \mathrm{~h}$. During the fermentation period, changes in $\mathrm{pH}$ titratable acidity (acid concentration) and total solids were measured at hour 0 and hour 24 . At the same time (hour 0 and hour 24) samples were collected for microbial analysis (aerobic mesophylic bacteria, LAB and yeast). The schematic flow of cassava mahewu preparation is presented in Figure 1. 

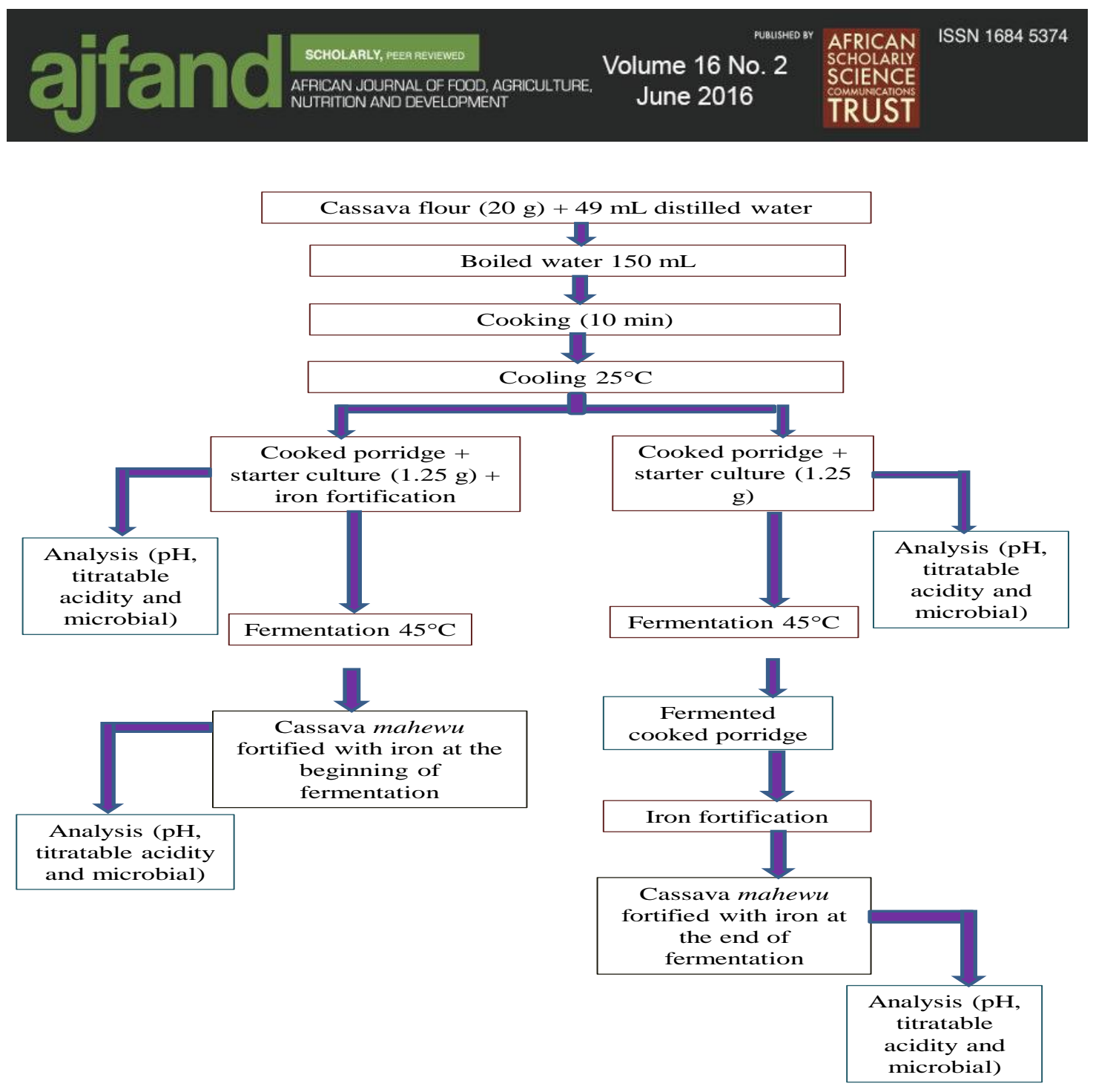

Figure 1: Schematic presentation of the preparation of cassava mahewu and indication of the stage at which iron is added

\section{pH changes, titratable acidity and total solids}

The $\mathrm{pH}$ of mahewu was measured just after the addition of the starter culture (time zero) and at hour 24 (end of the fermentation). The titratable acidity was determined by titration of $9 \mathrm{~mL}$ samples using $0.1 \mathrm{M} \mathrm{NaOH}$ with phenolphthalein as indicator. The concentration of acid was expressed as a percentage of lactic acid, according to the formula:

$$
\% \text { Lactic acid }=\frac{\text { Volume of } 0.1 \mathrm{M} \mathrm{NaOH}(\mathrm{mL}) \times \text { normality of } \mathrm{NaOH} \times \mathrm{Mol} w \mathrm{t} \text { of acid }}{\text { Volume of sample }(\mathrm{mL}) \times 10}
$$

Total solids were determined using a freeze drying technique (Freezone 6.1, Labconco). Before freeze drying, the freeze drier cups were washed, dried and put into a desiccator overnight. The mass of the freeze drier cups was determined, after which mahewu was transferred and the cups were reweighed. The mahewu in the cups was freeze-dried over a period of 5 days, and then reweighed. To express the results on a dry weight basis the following formula was used: 
Mass of dry sample

$\%$ Total solids $=\quad$ Mass of sample before freeze dry x 100

\section{Microbial analysis}

Serial dilutions of $1 \mathrm{~mL}$ fermented mahewu were prepared and plated on to Nutrient Agar (NA), Malt extract Agar (MEA) and de Man, Rogosa \& Sharpe (MRS) Agar (Merck Germany). The NA plates were incubated at $37^{\circ} \mathrm{C}$ for $24 \mathrm{~h}$, to assess presence of mesophylic aerobic bacteria. The MRS agar plates were incubated at $37^{\circ} \mathrm{C}$ for $48 \mathrm{~h}$ under anaerobic conditions, to assess growth of LAB. The MEA plates were incubated at $25^{\circ} \mathrm{C}$ for 5 days and checked daily for presence of yeast colonies. Colony counts were done at the end of the incubation period.

\section{Mahewu iron fortification}

Cassava mahewu was fortified with two different iron sources, ferrous sulfate $\left(\mathrm{FeSO}_{4} .7 \mathrm{H}_{2} \mathrm{O}\right)$ and ferrous fumarate $\left(\mathrm{C}_{4} \mathrm{H}_{2} \mathrm{FeO}_{4}\right)$, at two different stages of preparation. These were at the beginning (time zero when the starter culture was added) and at the end of fermentation (hour 24).

The "overage", which is the additional amount of the fortificant added to the flour, to compensate for storage and processing losses, was calculated as $1.2 \mathrm{mg}$ [15]. The amount of fortificant (ferrous sulfate or ferrous fumarate) added was calculated by taking the amount of iron present in each fortificant into consideration, which was according to the chemical formula. This resulted in $6.8 \mathrm{~g}$ ferrous sulfate or $3.8 \mathrm{~g}$ ferrous fumarate being dissolved in $100 \mathrm{~mL}$ of distilled water of which $1 \mathrm{~mL}$ of the solution was added to the mahewu. For fortification at the end of the fermentation process $(24 \mathrm{~h}), 6.2 \mathrm{~g}$ of ferrous sulfate or $3.45 \mathrm{~g}$ of ferrous fumarate, was dissolved in $100 \mathrm{~mL}$ distilled water and $1 \mathrm{~mL}$ of the solution added to the mahewu.

Samples taken to compare the effects of adding iron at the beginning or end of fermentation were in each case taken after the addition of the iron compound. That is to say sampling at time zero followed addition of iron and sampling at $24 \mathrm{~h}$, was also done after iron fortification, using each iron compound (Figure 1). This was the reason why the amount of iron added at the beginning differed from the amount of iron added at the end of the fermentation process.

\section{Statistical analysis}

Mahewu was prepared in duplicate for each variety of cassava (bitter or sweet). Samples for each repeat of bitter or sweet variety of cassava were taken in duplicate, to test for $\mathrm{pH}$ changes and titratable acidity. During microbial analysis serially diluted samples (10${ }^{1}$ to $10^{-6}$ ) of each repeat were plated in duplicate on each medium (NA, MRS and MEA). All data were analyzed using STATA version 12 with one-way analysis of variance (ANOVA) at $95 \%$ confidence level. 


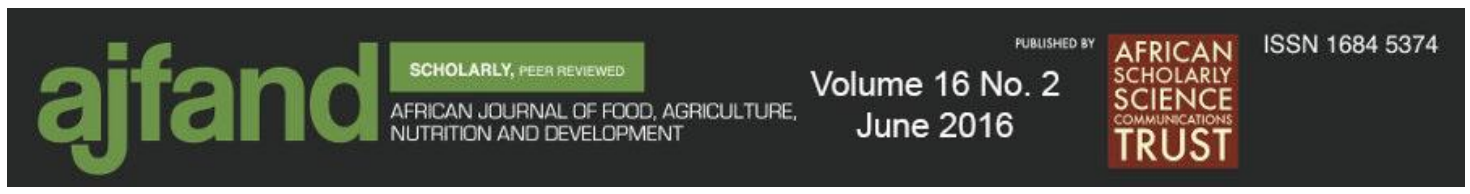

\section{RESULTS}

Table 1 shows the variation in $\mathrm{pH}$, titratable acidity and total solids during fermentation of sweet and bitter cassava. Mahewu was fortified using two different sources of iron, added either before or after fermentation. During the fermentation process, as the $\mathrm{pH}$ decreased, the acidity increased and the microorganisms multiplied. When mahewu made from bitter and sweet cassava were compared, there was no statistically significant difference in $\mathrm{pH}$ changes and titratable acidity at the $95 \%$ confidence level. There was also no significant difference in $\mathrm{pH}$ changes and titratable acidity between mahewu fortified at the beginning of fermentation or fortified after $24 \mathrm{~h}(p>0.05)$. The mean $\mathrm{pH}$, with and without fortification, at the start of the fermentation process was 6.08 (range 5.87-6.28) and at the end it was 4.52 (range 4.5-4.58). The average total solids in both mahewu made from bitter and sweet cassava, with and without iron fortification, was 9.65\% (range $8.90-10.22 \%$ ). The mean acidity at the beginning of fermentation was $0.07 \%$ (range $0.05-0.09 \%$ ) and after $24 \mathrm{~h}$ was $0.29 \%$ (range $0.24-0.35 \%$ ). The type of iron used for fortification did not significantly affect $\mathrm{pH}$, titratable acidity or total solids.

The microbial counts at time zero (beginning) and hour 24 (end) for the respective mediums, after the incubation periods, are presented in Table 2 . There was a significant increase in microbial counts of aerobic mesophylic bacteria, LAB and yeasts from 0 to $24 \mathrm{~h}$. There was no statistically significant difference $(p>0.05)$ between mahewu made from bitter cassava and sweet cassava, although microbial counts seemed to be higher in mahewu fortified at the beginning of fermentation with either ferrous sulfate or ferrous fumarate, (Table 2). Microbial counts appeared to be higher in the mahewu fortified with ferrous sulfate compared to mahewu fortified with ferrous fumarate, although there was no significant statistical difference. Fortified mahewu had slightly higher microbial counts when compared to the control (unfortified).

The parameters for the fermentation process are shown in Table 3. It can be seen that the mean $\mathrm{pH}$ of fortified cassava mahewu was 4.5 while the acidity was $0.29 \%$. The mean solid content of standardized fermented cassava mahewu was found to be $9.65 \%$.

\section{DISCUSSION}

The increase in $\mathrm{LAB}$ and yeast during fermentation from time zero to hour 24 (Table 2), suggested that these microorganisms were mainly responsible for the fermentation of the cassava mahewu. The importance of LAB and yeast in the fermentation of traditional foods, including cassava, has been described previously [5]. The association of LAB and yeast as fermentation agents, found in cassava mahewu is also in agreement with that which was previously reported for maize mahewu [16] and other fermented traditional drinks [17]. The LAB and yeast facilitate the breakdown of complex compounds, into simple and easily digestible substances that improve nutrient quality [18]. Yeast has also been related to the fermentation of other cassava products such as agbelima [19] and fufu [20]. Previous work has reported the influence of LAB and yeast in the development of typical characteristics including smell, taste, visual appearance, and consistency of fermented cassava foods [19]. 


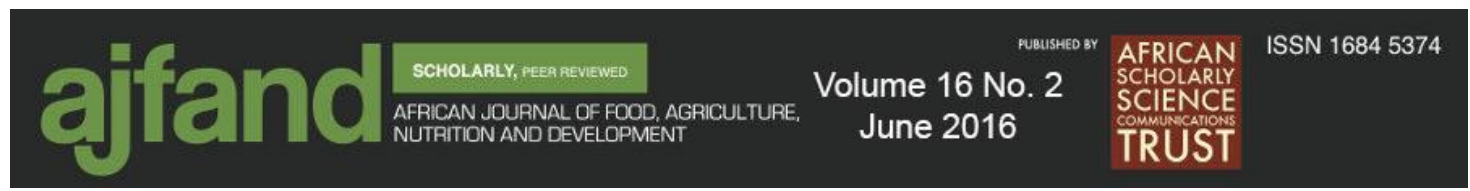

The high solubility of ferrous sulfate in water [21] explains the relatively higher microbial counts observed in cassava mahewu fortified with this iron source, although the difference was not significant. The WHO has found ferrous sulfate to be more suitable for food fortification [22]. However, no significant difference in fermentation parameters was found between mahewu made from bitter or sweet varieties of cassava fortified with either ferrous sulfate or ferrous fumarate. It is important that iron fortification of the bitter variety was equally successful, as this type predominates in Mozambique due to drought and pest resistance [23].

Fermentation may also increase bioavailability of iron after fortification. Previous studies on cassava fermentation have reported an increase in the bioavailability of minerals such as calcium, iron and zinc [24]. Cassava mahewu is known to contain an organic acid (lactic acid) which could also potentiate iron uptake. According to Teucher et al. [25] fermented foods with high levels of organic acids are appropriate vehicles for iron fortification.

During cassava mahewu fermentation, as the LAB multiplied, the $\mathrm{pH}$ declined and acidity increased, probably due to the transformation of sugar into lactic acid during fermentation. The latter favours the growth of yeast, which proliferates at a lower $\mathrm{pH}$. This finding is in agreement with Silva and Yang [26] who reported that $\mathrm{pH}$ is a key factor for growth of microorganisms. Cassava flour had been reported as being a good substrate for lactic acid production through fermentation [27].

The parameters of cassava mahewu in the present study differ from those observed in South African indigenous maize mahewu, which has been reported as having a $\mathrm{pH}$ between 2.74 and 3.5, with acidity between 0.4 and 0.5\% [28]. Bvochora et al. [4] produced maize mahewu under controlled conditions and obtained an acidity of $0.25 \%$ with a $\mathrm{pH}$ 3.5. Indigenous maize mahewu has been found to contain a solid substrate of 8 to $10 \%[3,4]$, which was in agreement with the solid substrate found in the present study.

Cassava has a different type and proportion of carbohydrates to maize and may not ferment in the same way, causing a different end point $\mathrm{pH}$ and acidity to that described for maize mahewu. These may also have been affected by the temperature and time of fermentation, amounts and proportions of flour and water, or type and volume of starter culture used. The variable results reported for maize mahewu, may have been due to variations in quality and quantity of microorganisms in the starter cultures. In the current study, starter cultures were freeze dried, resulting in high repeatability during fermentation.

\section{CONCLUSION}

A standardized method was developed to prepare and fortify cassava mahewu under controlled conditions. It is recommended that fortification occurs at the end of traditional fermentation when done at household level. This should be done by providing consumers with sachets, containing sugar fortified with either of the iron sources investigated, to be added to the beverage just before consumption. 


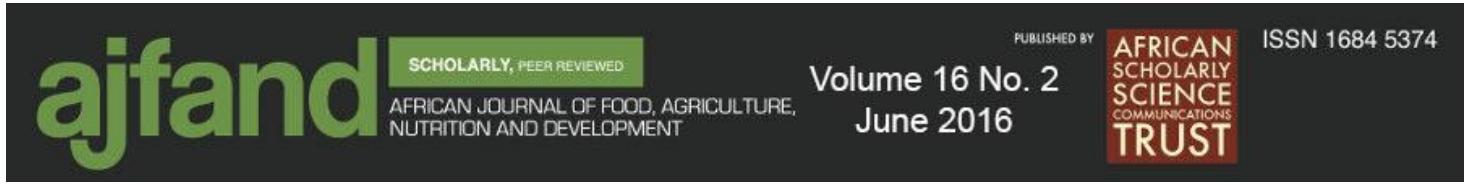

\section{ACKNOWLEDGEMENTS}

Financial assistance from the Graca Machel Scholarship Fund, the National Research Foundation and the Department of Food Science, University of Pretoria are gratefully acknowledged. Permission to undertake this study was granted by the Research Ethics Committee of the University of Pretoria (67/2013). 


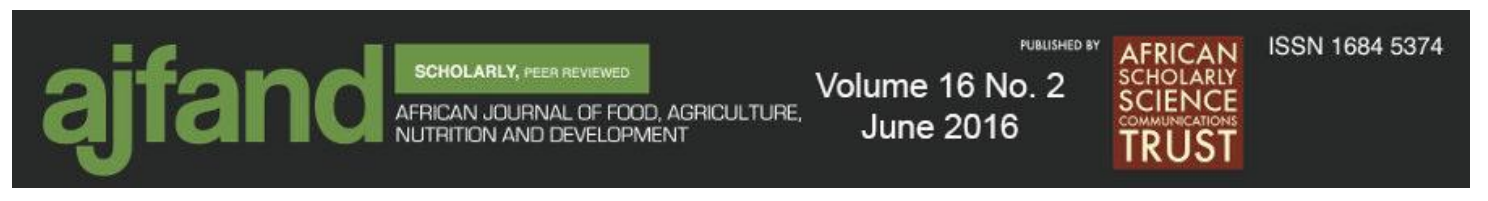

Table 1: pH changes, titratable acidity and total solids of cassava mahewu

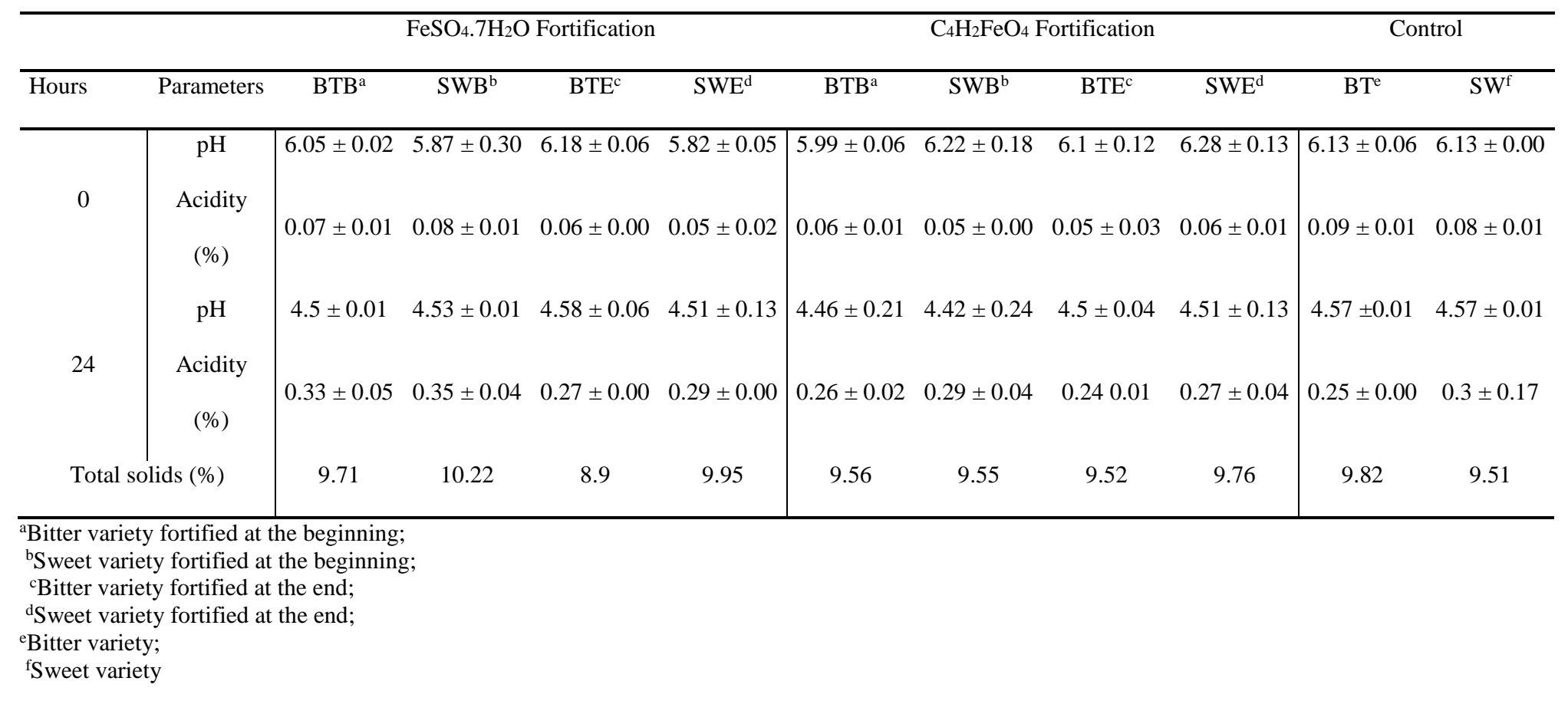




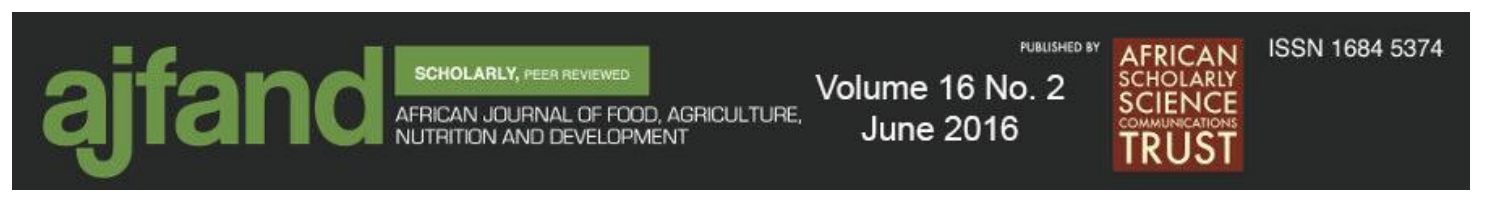

Table 2: Microbial counts (CFU/mL) and p values of iron fortified cassava mahewu at $0 \mathrm{~h}$ and $24 \mathrm{~h}$ fermentation

\begin{tabular}{|c|c|c|c|c|c|c|c|c|c|c|c|c|c|c|c|c|}
\hline & \multicolumn{7}{|c|}{$\mathrm{FeSO}_{4} .7 \mathrm{H}_{2} \mathrm{O}$ Fortification } & \multicolumn{6}{|c|}{$\mathrm{C}_{4} \mathrm{H}_{2} \mathrm{FeO}_{4}$ Fortification } & \multicolumn{3}{|c|}{$\mathrm{C}_{4} \mathrm{H}_{2} \mathrm{FeO}_{4}$ Fortification } \\
\hline & Hour & $\mathrm{BTB}^{\mathrm{a}}$ & $\mathrm{BTE}^{\mathrm{b}}$ & $p^{\mathrm{c}}$ & $\mathrm{SWB}^{\mathrm{d}}$ & $\mathrm{SWE}^{\mathrm{e}}$ & $p^{\mathrm{c}}$ & $\mathrm{BTB}^{\mathrm{a}}$ & $\mathrm{BTE}^{\mathrm{b}}$ & $p^{\mathrm{c}}$ & $\mathrm{SWB}^{\mathrm{d}}$ & $\mathrm{SWE}^{\mathrm{e}}$ & $p^{\mathrm{c}}$ & $\mathrm{BT}^{\mathrm{f}}$ & $\mathrm{SW}^{\mathrm{g}}$ & $p^{\mathrm{c}}$ \\
\hline Aerobic & 0 & $5.68 \pm 0.02$ & $5.7 \pm 0.01$ & 0.2 & $5.71 \pm 0.06$ & $5.56 \pm 0.04$ & 0.07 & $4.95 \pm 0.11$ & $4.8 \pm 0.14$ & 0.55 & $4.55 \pm 0.01$ & $4.8 \pm 0.10$ & 0.17 & $4.01 \pm 0.00$ & $4.1 \pm 0.12$ & 0.4 \\
\hline $\begin{array}{c}\text { mesophylic } \\
\text { bacteria }\end{array}$ & 24 & $7.96 \pm 0.10$ & $7.67 \pm 0.22$ & 0.19 & $7.69 \pm 0.15$ & $7.15 \pm 0.15$ & 0 & $7.83 \pm 0.04$ & $7.57 \pm 0.07$ & 0.19 & $7.57 \pm 0.60$ & $7.45 \pm 0.21$ & 0.87 & $7.12 \pm 0.02$ & $7.59 \pm 0.01$ & 0 \\
\hline Lactic acid & 0 & $3.86 \pm 0.42$ & $4.06 \pm 0.00$ & 0.62 & $4.21 \pm 0.44$ & $3.88 \pm 1.05$ & 0.8 & $3.95 \pm 0.17$ & $3.8 \pm 0.01$ & 0.46 & $3.56 \pm 0.70$ & $3.3 \pm 0.01$ & 0.69 & $3.59 \pm 0.65$ & $3.84 \pm 0.04$ & 0.64 \\
\hline bacteria & 24 & $7.72 \pm 0.26$ & $7.31 \pm 0.01$ & 0.34 & $7.11 \pm 0.25$ & $7.53 \pm 0.10$ & 0.34 & $7.52 \pm 0.25$ & $7.51 \pm 0.03$ & 0.96 & $7.51 \pm 0.02$ & $7.5 \pm 0.12$ & 0.93 & $7.22 \pm 0.05$ & $7.17 \pm 0.08$ & 0.61 \\
\hline & 0 & $3.41 \pm 0.00$ & $2.93 \pm 0.32$ & 0.28 & $3.28 \pm 0.87$ & $3.48 \pm 0.49$ & 0.66 & $3.86 \pm 0.88$ & $3.18 \pm 0.80$ & 0.67 & $3.52 \pm 0.32$ & $3.4 \pm 0.54$ & 0.59 & $3.86 \pm 0.21$ & $3.76 \pm 0.00$ & 0.56 \\
\hline & 24 & $6.84 \pm 0.46$ & $6.83 \pm 0.30$ & 0.94 & $7.04 \pm 0.19$ & $6.71 \pm 0.72$ & 0.69 & $7.43 \pm 0.06$ & $7.46 \pm 0.32$ & 0.96 & $7.51 \pm 0.01$ & $7.25 \pm 0.45$ & 0.57 & $5.91 \pm 0.51$ & $6.82 \pm 0.16$ & 0.14 \\
\hline
\end{tabular}

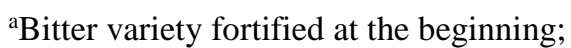

${ }^{b}$ Bitter variety fortified at the end;

${ }^{\mathrm{c}} \mathrm{p}$ value ( $p<0.05$ values within the same row are significantly different; $p>0.05$ values within the same row not significantly different)

${ }^{\mathrm{d}}$ Sweet variety fortified at the beginning;

${ }^{\mathrm{e} S}$ weet variety fortified at the end;

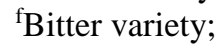

${ }^{\mathrm{g}}$ Sweet variety. 


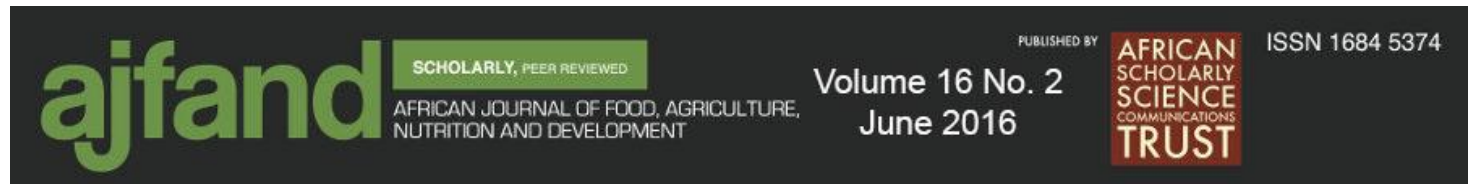

Table 3: Parameters for standardized preparation of iron fortified traditional cassava mahewu in Mozambique

\begin{tabular}{|c|c|c|}
\hline & Mahewu fortified with $\mathrm{FeSO}_{4} .7 \mathrm{H}_{2} \mathrm{O}$ & Mahewu fortified with $\mathrm{C}_{4} \mathrm{H}_{2} \mathrm{FeO}_{4}$ \\
\hline Amount of cassava flour & $20 \mathrm{~g}$ & $20 \mathrm{~g}$ \\
\hline Total amount of water & $200 \mathrm{ml}$ & $200 \mathrm{ml}$ \\
\hline amount of starter culture & $1.25 \mathrm{~g}$ & $1.25 \mathrm{~g}$ \\
\hline Fermentation temperature & $45^{\circ} \mathrm{C}$ & $45^{\circ} \mathrm{C}$ \\
\hline Cooking time & 10 minutes & 10 minutes \\
\hline Iron added at beginning & $6.8 \mathrm{mg}$ & $3.8 \mathrm{mg}$ \\
\hline Iron added at end & $6.2 \mathrm{mg}$ & $3.45 \mathrm{mg}$ \\
\hline $\mathrm{pH}$ before fermentation & 5.98 & 6.15 \\
\hline $\mathrm{pH}$ after fermentation & 4.53 & 4.47 \\
\hline$\%$ lactic acid before fermentation & 0.065 & 0.055 \\
\hline$\%$ lactic acid after fermentation & 0.31 & 0.27 \\
\hline Total solids (\%) & 9.7 & 9.6 \\
\hline
\end{tabular}




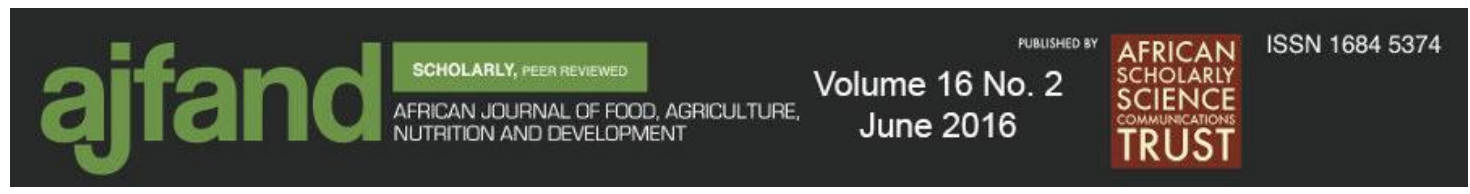

\section{REFERENCES}

1. INE (Instituto Nacional de Estatíscas) National institute of Statistics. Censo Agro-pecuário (Agriculture and Livestock Census) 2009-2010: Resultados definitivos (Definitive results), 2011 Available from: http://www.ine.gov.mz/censos_dir/agro-pecuaria/CAP_VF.pdf. Accessed on 03 June 2014.

2. Holzapfel WH and JL Taljaard Industrialization of mageu fermentation in South Africa. In: KH Steinkraus (Ed). Industrialization of indigenous fermented foods New York: Marcel Dekker, 2004: 363-407.

3. Mutasa MP and AD Ayebo Fermentation of mahewu using a maize meal base. Zimbabwe Sci. News.1993; 27: 86-89.

4. Bvochora JM, Reed JD, Read JS and R Zvauya Effect of fermentation processes on proanthocyanidins in sorghum during preparation of Mahewu, a non-alcoholic beverage. Process Biochem. 1999; 35: 21-25.

5. Matsheka MI, Magwamba CC, Mpuchane S and BA Gashe Biogenic amine producing bacteria associated with three different commercially fermented beverages in Botswana. Afr. J. Microbiol. Res. 2013; 7(4): 342-350.

6. Nout RMJ Rich nutrition from the poorest-cereal fermentation in Africa and Asia. Food Microbiol. 2009; 26: 685-692.

7. Chelule PK, Mbongwa HP, Carries $\mathbf{S}$ and $\mathbf{N}$ Gqaleni Lactic acid fermentation improves the quality of amahewu, a traditional South African maize-based porridge. Food Chem. 2010; 122: 656-661.

8. WHO. Worldwide prevalence of anemia (1993 - 2005): WHO global database on anemia. Geneva: World Health Organization; 2008.

9. FFI. Flour Fortification Initiative 2013 Available from: http://www.ffinetwork.org/index.html. Accessed on 07 April, 2015.

10. Moretti D, Biebinger R, Bruins MJ, Bruins B and K Kraemer Bioavailability of iron, zinc, folic acid, and vitamin A from fortified maize. Ann. NY. Acad. Sci. 2014; 1312: 54-65.

11. Moretti D, Zimmermann MB, Wegmuller R, Walczyk T, Zeder C and $\mathbf{R}$ Hurrell Iron status and food matrix strongly affect the relative bioavailability of ferric pyrophosphate in humans. Am. J. Clin. Nutr. 2006; 83(3): 632-638.

12. Das JK, Salam RA, Kumar R and ZA Bhutta Micronutrient fortification of food and its impact on woman and child health: a systematic review. Syst Rev 2013; 2(63): 1-24. 
13. FFI. WHO Recommendations on wheat flour fortification. UNICEF/FFI Joint workshop, Ankara 12-13 June 2012. Addressing micronutrient deficiencies through flour fortification in the CEE/CIS region. Available at: http://www.ffinetwork.org/plan/standards.html. Accessed April 13, 2015.

14. Salvador EM Development of iron fortified cassava mahewu. Doctoral thesis. University of Pretoria, South Africa; 2015.

15. USA. Code of Federal Regulations 1998; 197(260). Available at: www.dsm.com/content/dam/dsm/nip/en_US/documents/corn.pdf. Accessed June 20, 2012.

16. Houinhouigan DJ, Nout RMJ, Nago CM, Houben JH and FM Rombouts Microbiological changes in mawe during natural fermentation. World $J$. Microbiol. Biotechnol. 1994; 10: 410-413.

17. Jespersen $\mathbf{L}$ Occurrence and taxonomic characteristics of strains of Saccharomyces cerevisiae predominant in African indigenous fermented foods and beverages. FEMS. Yeast Res. 2003; 3: 191-200.

18. Olasupo NA, Olukoya DK and SA Odunfa Studies on local strains of amylolytic Lactobacillus from Nigerian fermented foods. Die Nahrungn. 1996; 40(1): 45-46.

19. Amoa-Awua WKA, Filtenborg O, Sefa-Dedeh $\mathbf{S}$ and $\mathbf{M}$ Jakobsen The contribution of moulds and yeasts to cassava dough 'agbelima' fermentation. $J$. Appl. Microbiol. 1997; 83: 288-296.

20. Oyewole OB Characteristics and significance of yeasts' involvement in cassava fermentation for 'fufu' production. Int. J. Food Microbiol. 2001; 6: 213-218.

21. Harrington M, Hotz C, Zeder C, Polvo GO, Villalpando S, Zimmermann MB, Walczyk T, Rivera JA and RF Hurrell A comparison of the bioavailability of ferrous fumarate and ferrous sulfate in non-anemic Mexican women and children consuming a sweetened maize and milk drink. Eur. J. Clin. Nutr. 2011; 65: 20-25.

22. WHO/FAO. World Health Organization and Food and Agriculture Organization of the United Nations Guidelines on Food Fortification with Micronutrients. 2006, WHO/FAO Geneva, 1-376.

23. MIC (Ministério de Industria e Comercio) /FAO/EC Analysis of cassava as a target product from Mozambique and in particular to South Africa: External market task force. MIC/FAO/EC; 2004:1-99. Maputo, Mozambique.

24. Adewusi SRA, Ojumu TV and OS Falade The effect of processing on total organic acids content and mineral availability of simulated cassava-vegetable diets. Plant Foods. J. Hum. Nutr. 1999; 53: 367-380. 


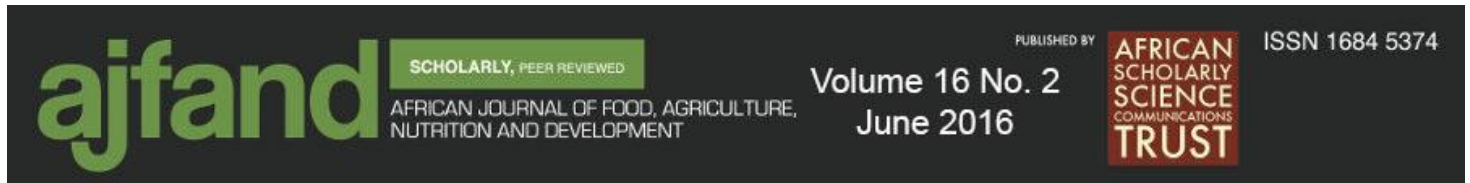

25. Teucher B, Olivares $\mathbf{M}$ and $\mathbf{H}$ Cori Enhancers of iron Absorption: Ascorbic acid and other organic acids. Int. J. Vitam. Nutr. Res. 2004; 74(6): 403-419.

26. Silva E and $\mathbf{S}$ Yang Kinetics and stability of a fibrous-bed bioreactor for continuous production of lactic from unsupplemented acid whey. J. Biotechnol. 1995; 41(1): 59-70.

27. Quintero JE, Acosta A, Mejia C, Rios R and AM Torres Lactic acid production via cassava-flourhydrolysate fermentation. Vitae Columbia. 2012; 19(3): 287-293.

28. Holzapfel WH Industrialization of mageu (mahewu) and sorghum beer fermentation. In: A Westby, PJA Reilly (Ed). Proceedings of a Regional Workshop of International Foundation for Science on Traditional African Foods: Quality and Nutrition. Dar es Salaam 1991: 79-86. 